\title{
Pemahaman Komunitas Penyandang Disabilitas Muslim terhadap CRPD
}

\author{
1* Rachmad Gustomy \\ ${ }^{1}$ Jurusan Ilmu Pemerintahan, Universitas Brawijaya, Malang Indonesia; \\ Pusat Studi Pesantren dan Pemberdayaan Masyarakat Universitas Brawijaya
}

\begin{abstract}
Penelitian ini dimaksudkan untuk mengetahui seberapa jauh pemahaman penyandang disabilitas muslim terhadap hak-haknya sebagaimana tertuang dalam CRPD. Tujuannya penelitian adalah untuk memahami persepsi CRPD kelompok muslim untuk menjadi landasan bagi kebijakan publik agar tidak distortif terhadap kepentingan penyandang disabilitas. Selain itu kepentingan dari studi ini adalah agar menjadi rujukan bagi advokasi atau program pemberdayaan tentang prioritas utama yang dibutuhkan oleh penyandang disabilitas. Penelitian dilakukan kepada kelompok pengaiian difabel di dua kota, malang dan Mojokerto, dengan jumlah responden 41. Hasil dari temuan ini menunjukkan bahwa masih banyak penyandang disabilitas yang belum memahami haknya yang tertuang dalam CRPD. Oleh karena itu sangat penting untuk memberikan penguatan kesadaran kelompok penyandang disabilitas terhadap haknya dalam kajian keagamaan.
\end{abstract}

Keywords: CRPD, peyandang disabilitas muslim, hak-hak disabilitas

\section{Latar belakang}

Jumlah penyandang disabilitas di dunia berdasarkan data International Labour Organizaton (ILO) telah mencapai 15 persen (kurang lebih 1 miliar jiwa) dari penduduk dunia (ILO, 2013). Dari jumlah tersebut sebesar 80 persen tinggal di negara berkembang dan 50 persen dari mereka tidak terpenuhi perawatan medisnya(Anadolu Agency Online, 2018). Di Indonesia, menurut data Survei Penduduk Antar Sensus (SUPAS) 2015 jumlah penyandang disabilitas adalah 21, 84 juta jiwa(Koran Tempo Online, 2019). Jumlah sebesar ini tentu memerlukan perhatian utama dari berbagai elemen dunia dalam pemenuhan hak-hak dasar bagi penyandang disabilitas. Convention on the Rights of Persons with Disabilities/CRPD (Konvensi Hak-hak Penyandang Disabilitas) menandai fokus dunia pada hak-hak penyandang disabilitas oleh
Perserikatan Bangsa-Bangsa (PBB) tanggal 13 Desember 2006 (PPDI Online, 2017). Konvensi ini menjadi angin segar bagi permasalahan yang dihadapi oleh kelompok masyarakat yang mengalami gangguan fisik maupun mental.

Indonesia menjadi salah satu negara yang terlibat aktif memperhatikan masalah disabilitas. Secara ideal, persoalan pemenuhan hak-hak penyandang disabilitas harus menjadi perhatian seluruh elemen masyarakat bukan hanya pemerintah. Berdasarkan data PUSDATIN, jumlah penyandang disabilitas di Indonesia cukup banyak dan perlu mendapatkan perhatian lebih serius. Hal-hal yang penting untuk diperhatikan adalah hak-hak bagi penyandang disabilitas agar terjamin kehidupannya. Penyandang disabilitas 
bukan hanya dilihat dari gangguan fisik atau mental saja, melainkan sisi lainnya seperti kemiskinan, aksesibilitas, kesempatan kerja, dan sebagainya.

Secara garis besar, seluruh warga negara sekali pun penyandang disabilitas memiliki hak-hak sebagaimana dalam UUD 1945 pasal 28A yang menyebutkan bahwa 'setiap orang berbak untuk bidup serta berbak mempertahankan bidup dan kehidupannya'. Kerangka konstitusional inilah yang menjadi dasar utama pentingnya mengawal pemenuhan hakhak penyandang disabilitas di Indonesia. Undang-undang Nomor 19 Tahun 2011 tentang Pengesahan Convention on the Rights of Persons with Disabilities (Konvensi Hak-hak Penyandang Disabilitas) hasil ratifikasi konvensi internasional PBB menunjukkan keseriusan pemerintah Indonesia dalam memperhatikan hak-hak bagi penyadang disabilitas.

Hak-hak penyandang disabilitas seringkali terabaikan, sebagai contoh dalam hal mendapatkan pelayanan kesehatan. Penyandang disabilitas seringkali disamakan dengan orang normal oleh penyedia layanan kesehatan seperti antrian yang seharusnya didahulukan. Padahal, hal tersebut telah disebutkan dalam pasal 29 UU No. 25 Tahun 2009 tentang Layanan Publik bahwa 'penyedia layanan umum harus memberikan layanan khusus kepada penyandang disabilitas sesuai dengan peraturan'. Pertanyaan besar yang muncul kemudian adalah hak yang tertuang dalam regulasi tersebut diketahui bahkan dipahami oleh penyandang disabilitas atau tidak. Di balik kekurangan yang dimiliki oleh penyandang disabilitas, faktanya sangat sedikit pula yang berani menyuarakan aspirasi atau memperjuangkan hak-haknya sebagai penyandang disabilitas. Implikasinya adalah seringkali justru dimanfaatkan oleh orang-orang yang tidak bertanggung jawab dan menunggangi kepentingan penyandang disabilitas. Oleh karena itu, penting menjadi perhatian utama adalah memastikan penyandang disabilitas memahami hak-hak khususnya.

Lemahnya pemahaman kelompok disabilitas terkait hak-haknya baik dalam CRPD maupun peraturan perundangundangan lain yang mengakomodasi kelompok difabel dapat dibaca pada beberapa studi terdahulu, seperti dua survey yang pernah dilakukan oleh Pusat Studi dan Layanan Disabilitas (PSLD) Universitas Brawijaya. Dari beberapa muatan pertanyaan, para kelompok difabel tidak banyak tahu terkait hak yang seharusnya diperoleh, mulai dari aksesibilitas, pendidikan, ekonomi, maupun hukum. Hal tersebut menjadi pembuktian bahwa kelompok difabelpun tidak memiliki cukup semangat untuk mengetahui apa yang seharusnya menjadi hak mereka. Kelompok difabel hanya bisa menuntut, atau bahkan menyerah pada keadaan yang ada. Stigma ini kemudian semakin mengakar kuat di mindset kelompok difabel, sehingga tidak ada perubahan nasib cukup signifikan yang dirasakan baik tidak ada regulasi maupun setelah adanya regulasi. Semua argumen yang telah dipaparkan di atas akan semakin memperkuat posisi urgensi penelitian ini. Dengan memahami pengetahuan kelompok difabel atas hak yang dimiliki pada akhirnya akan sampai pada usaha mereka untuk semakin memperjuangkan hak-hak yang belum diperoleh. Baik itu hak yang belum dipenuhi berbagai instansi seperti dalam regulasi maupun hak lain yang mungkin saja belum dituangkan dalam regulasi.

\section{Kerangka Teori}

\subsection{Logika Hak Disabilitas}

Hak penyandang disabilitas merupakan salah satu bentuk hak asasi 
manusia yang saat ini menjadi sorotan utama mengingat tingginya perhatian atas keterbatasan kelompok difabel. Secara umum, dikenal adanya dua pendekatan dalam isu HAM penyandang disabilitas, yaitu Pendekatan tradisional dan pendekatan yang menolak sikap paternalistik. Pendekatan yang pertama memandang difabel bukanlah bagian dari isu kesehatan dan kesejahteraan, sehingga perbuatan baik kepada mereka hanya sebatas dorongan moral(Pawestri, 2017). Pendekatan kedua memberikan pemahaman bahwa isu kesejahteraan dan kesehatan penyandang disabilitas adalah bagian dari perjuangan komunitas masyarakat secara keseluruhan karena prinsip kesetaraan hak (Pawestri, 2017). Pentingnya isu disabilitas ini kemudian memunculkan beberapa peraturan yang digunakan sebagai acuan dalam melindungi hak-hak kelompok disabilitas. Salah satu rujukan paling penting datang dari Convention on The Right of Persons With Disabilities (Konvensi Mengenai Hak-Hak Penyandang Disabilitas) atau lazim disebut sebagai CRPD.

CRPD muncul setelah Majelis Umum Perserikatan Bangsa-Bangsa (PBB) mengeluarkan Resolusi Nomer A/61/106 pada tanggal 13 Desember 2013 (UU Nomor 19 Tahun 2011). Konvensi tersebut secara garis besar memuat hak-hak yang harus diberikan kepada penyandang disabilitas, serta bagaimana kemudian langkah-langkah yang dilakukan untuk menjamin pelaksanaan konvensi tersebut. Logika dibalik CRPD menitik beratkan pada pengakuan bahwa setiap manusia pada dasarnya sama, tak terkecuali penyandang disabilitas (cacat) yang juga harus menikmati kebebasan sebagai seorang manusia dan tak boleh dibeda-bedakan. Pernyataan tersebut memperlihatkan bahwa telah terjadi pergeseran mendasar dalam melihat realitas disabilitas, disabilitas dianggap lebih mampu dijelaskan menggunakan pendekatanpendekatan hak asasi manusia. Untuk itu, para penyandang disabilitas harus bebas dari segala jenis perlakuan kasar seperti misalnya penyiksaan, eksploitasi, serta berbagai perlakuan semena-mena. Karena pada dasarnya lingkungan dan prilaku seseoranglah yang telah menciptakan keterbatasan bagi penyandang disabilitas dalam berpartisipasi di masyarakat secara penuh bersama orang-orang lain (Pusham Online, 2016) .

Pengakuan bahwa hak disabilitas merupakan bagian dari hak asasi manusia secara nyata berimplikasi langsung terhadap tanggung jawab yang harus dipegang oleh negara. Negara diposisikan sebagai lembaga yang wajib merealisasikan berbagai hak-hak yang telah dituangkan dalam konvensi tersebut melalui berbagai peraturan perundangundangan, atauran hukum, serta aturanaturan administratif. Untuk itu PBB menempatkan negara sebagai lembaga yang menjadi sorotan utama dalam pemenuhan hak-hak disabilitas menurut CRPD. Dengan diakuinya hak disablitas oleh negara menjadi bagian dari dikriminasi atas hukum hak asasi manusia, maka dukungan lebih intensif akan semakin kuat karena telah memiliki legitimasi hukum yang jelas.

Dari beberapa poin tentang perlindungan yang diwajibkan dalam butir konvensi CRPD, beberapa di antaranya menjadi rentan dan harus mendapatkan perhatian utama oleh pemerintah. Seperti misalnya perlindungan terhadap perempuan dan anak-anak disabilitas. Di samping itu, kesetaraan di depan hukum, akses/kesempatan mendapatkan keadilan, kebebasan dan keamanan, 
perlindungan dari berbagai perlakuan penyiksaan, kebebasan atas perbudakan dan eksploitasi, dan kebebasan berbicara dan menyatakan pendapat harus menjadi prioritas utama. Bukan karena seluruh hak merupakan domain yang paling mampu dipenuhi oleh negara, namun lebih karena regulasi yang dikeluarkan oleh negara tak jarang memperlihatkan sikap diskriminatif terhadap kelompok disabilitas. Pertanyaan selanjutnya adalah bagaimana kemudian butir-butir kesepakatan di dalam CRPD dapat dituangkan dalam bentuk aksi nyata di masyarakat? Bagaimana kemudian Indonesia yang juga telah melakukan ratifikasi terhadap CRPD mampu menerapkannya dalam regulasi-regulasi yang telah dikeluarkannya? Pertanyaanpertanyaan tersebut untuk selanjutnya akan dijelaskan dalam sub bab selanjutnya di bawah ini.

\subsection{Affirmative Action CRPD di Indonesia}

Setelah melakukan rativikasi terhadap Convention on The Right of Persons With Disabilities pada tahun 2007 di New York, pemerintah akhirnya mengeluarkan UU No. 19 Tahun 2011 tentang Pengesahan Convention On The Right of Persons With Disabilities (Konvensi Mengenai Hak-Hak penyandang Disabilitas). Catatan penting yang perlu diperhatikan adalah dalam menandatangani konvensi tersebut Indonesia melakukannya tanpa melakukan melakukan reservasi. Artinya Indonesia menerima seluruh isi konvensi tersebut tanpa terkecuali.

Namun setelah melakukan ratifikasi, CRPD memunculkan kontroversi baru terhadap penerapannya di Indonesia. Pertama, beberapa butir yang menjadi tugas negara dalam memenuhi hak disabilitas menjadi bertentangan dengan regulasi yang sebelumnya telah diterapkan di Indonesia. Salah satunya misalnya ketika disabilitas tidak cakap atau berkedudukan sama di mata hukum. Kelompok disabilitas dianggap rentan karena posisinya menang direntankan oleh teks serta sistem hukum negara tersebut. Akhirnya kelompok disabilitas tetap menjadi kelompok minoritas yang pada akhirnya akan menghadapi pengorbanan ganda (double victimization), di satu sisi menjadi korban kejahatan dan di sisi lain menjadi korban atas stigma negative dari pemikiran sempit masyarakat (Pusham Online, 2016).

Kedua, perbedaan logika pendekatan antara CRPD dengan logika pendekatan penerapan undang-undang hak-hak disabilitas di Indonesia sebelumnya yang telah diterapkan. Jika CRPD fokus pada pendekatan hak asasi manusia, sedangkan pendekatan hak asasi difabel di Indonesia cenderung lebih legalisme positivistic. Akhirnya ketika CRPD juga diterapkan melalui UU No. 19 Tahun 2011 hasilnya akan sama, butirbutir pemenuhan hak difabel dalam CRPD akan ditafsirkan dalam bentuk legalisme positivistic. Inilah yang kemudian menjadikan setiap UU perlindungan disabilitas selamanya tidak akan mampu diterapkan dengan baik di lapangan. Untuk itulah kemudian diperlukan pemahaman ulang tentang hak-hak kelompok disbilitas, salah satunya melalui penerapan butir-butir CRPD dengan support undang-undang disabilitas sebelumnya yang telah ada di Indonesia. Terutama untuk beberapa variabelvariabel yang dianggap urgent diterapkan di Indonesia terkait hak-hak kelompok minoritas.

\subsection{Variabel CRPD dalam Pemenuhan Hak Disabel di Indonesia}


Terdapat empat hak penting yang menjadi konsen utama di dalam CRPD, di samping beberapa hak lainnya. Empat hak yang kemudian digunakan dalam penelitian ini sebagai indikator dalam mengukur persepsi kelompok difabel terkait hak mereka. Keempat hak tersebut adalah:

1. Hak Aksesibilitas. Pada CRPD hak aksesibilitas termuat dalam pasal 9 ayat 1a yang berbunyi bahwa tempat-tempat aksesibel seperti bangunan, jalan, transportasi, tempat-tempat di dalam dan di luar ruangan seperti sekolah, perumahan, rumah sakit, puskesmas dan klinik, serta tempat kerja. Penelitian ini membagi hak aksesibilitas tersebut setidaknya pada 3 indikator, yaitu aksesibilitas kelompok difabel pada infrastruktur-infrastruktur publik. Aksesibilitas kelompok difabel pada sarana-sarana transportasi. Terakhir adalah aksesibilitas kelompok difabel pada bidang kesehatan. Poin inilah yang harus diperkuat oleh pemerintah, karena pada kenyataannya banyak difabel tidak mendapatkan hak kesehatan yang layak dari negara, seperti misalnya banyaknya kelompok difabel tidak mendapatkan kartu Jamkesmas dari negara.

2. Hak pendidikan. Kelompok difabel menjadi rentan terabaikan dalam hak pendidikan, bukan hanya karena difabel memerlukan kebutuhan khusus terutama infrastruktur tetapi lebih karena kegagalan negara dalam mempertegas peratusan serta pengawasan hak disabilitas dalam bidang pendidikan.
3. Hak ekonomi. Hak ini mungkin juga menjadi paling urgent dibutuhkan oleh kelompok disabilitas di Indonesia. Realitasnya masih banyak kelompok disabilitas tidak dapat mengakses lapangan pekerjaan yang layak, terutama di bidangbidang formal. Sebagian besar kelompok disabilitas terserap pada sektor-sektor pekerjaan informal. Hingga poin RCPD terhadap pemenuhan ekonomi harus segera dilaksanakan oleh pemerintah.

4. Kesetaraan di depan hukum. Banyaknya permasalahan hukum yang melibatkan kelompok difabel terutama untuk kasus penyiksaan dan kekejaman menyebabkan penerapan poin kesetaraan di depan hukum bagi kelompok difabel menurut CRPD harus segera dilakukan. Disebutkan dalam CRPD bahwa negara harus menjamin segala kebutuhan dan rehabilitasi kesehatan bagi kelompok difabel.

\section{Metode penelitian}

Jenis penelitian yang akan digunakan adalah penelitian kuantitatif. Penelitian ini akan menggunakan survei deskriptif sebagai metode pencarian data, penelitian akan dilakukan dengan mengambil sampel dari populasi kelompok difabel. Mengingat konteks difabel yang tersebar dengan data yang tidak tertata rapi, maka penelitian ini akan dilakukan dengan melakukan survei di dua Kota yang mengambil sampling kelompok pengajian difabel. Proses ini dilakukan untuk ditemukan kejadiankejadian relatif, distribusi, dan hubunganhubungan antar variabel, sosiologis maupun psikologis. Sampling akan diambil dengan metode stratified sampling 
yang diambil dari kelompok penegajian difabel yang tersebar

di dua kota di Provinsi Jawa Timur, yakni Kota Malang dengan 19 responden (atau 46,3 \%) dan Kota Mojokerto dengan 22 koresponden (atau $53,7 \%$. Total koresponden pada penelitian ini berjumlah 41 koresponden. Dari total 41 koresponden tersebut, koresponden laki-laki berjumlah 23 orang $(56,1 \%)$ dan koresponden perempuan berjumlah 18 orang (43,9\%). Sebagian besar koresponden berasal dari tuna daksa dengan jumlah 29 orang $(70,7$ $\%)$, Tuna netra berjumlah 7 orang $(17,1$ $\%)$, tuna tungu 2 orang (4,9\%), lumpuh 1 orang $(2,4 \%)$, sedangkan 2 orang lagi tidak menjawab jenis disabilitas yang dialami.

Penelitian ini berhasil mengidentifikasi atau mengelompokkan empat indikator yang digunakan sebagai gambaran pemahaman kelompok difabel atas hak-hak mereka. Terutama hak yang dituangkan dalam Conventions on The Rights of Persons with Disabilities (CRPD), dimana kemudian telah diratifikasi oleh pemerintah menjadi Undang-Undang No. 11 Tahun 2009 tentang Pengesahan Conventions on The Rights of Persons with Disabilities (Konvensi Hak-Hak Penyandang Disabilitas. Keempat indikator tersebut adalah aksesibilitas, pendidikan, ekonomi, dan hukum.

\section{Pembahasan}

\subsection{Indikator Aksesibilitas Kelompok Difabel}

Meskipun menjadi hak paling mendasar yang harus dipenuhi bagi kelompok difabel, namun kenyataannya beradasarkan survey fasilitas publik dilakukan oleh PSLD UB terlihat bahwa sebagaian besar fasilitas publik tidak aksesibel dengan para kelompok difabel khususnya temuan di Kota Malang
(Thohari, 2013). Pertanyannya kemudian apakah kelompok difabel tersebut mengetahui bahwa aksesibilitas merupakan hak dasar mereka yang telah tertuang dalam peraturan perundangundangan maupun CRPD dan wajib dipenuhi oleh pemerintah maupun instansi terkait. Hasil survey di bawah ini dapat dijadikan acuan untuk menjawab pertanyaan tersebut. Terutama aksesibilitas pada bidang infrastruktur fasilitas publik, transportasi, dan kesehatan.

\section{- Aksesibilitas Fasilitas Publik}

Aksesibilitas fasilitas publik bagi kelompok difabel setidaknya telah dituangkan dalam dua peraturan pemerintah. Pertama, berdasarkan UU No. 28 Tahun 2002 tentang Bangunan Gedung pasal 27 ayat 2 yang menyatakan bahwa "Kemudahan bubungan ke, dari, dan di dalam bangunan gedung sebagaimana dimaksud dalam ayat (1) meliputi tersedianya fasilitas dan akesesibilitas yang mudah, aman, dan nyaman termasuk bagi penyandang cacat dan lanjut usia." Pasal tersebut kemudian diperkuat kembali dalam pasal 31 ayat (1), (2), dan (3).

Merujuk pada peraturan tersebut, untuk mengetahui persepsi maupun pemahaman kelompok difabel terhadap aksesibilitas fasilitas publik setidaknya ditanyakan dua pertanyaan utama yakni "apakah tempat-tempat publik telah aksesibel baki kelompok disabilitas?" dan "apakah anda pernah mendengar atau tahu ada aturan yang mengharuskan tempat publik harus aksesibel?" Hasilnya adalah untuk pertanyaan pertama sebagian besar kelompok difabel masih menganggap tempat publik kurang aksesibel (70, persen). Lebih jelasnya 
seperti yang ada dalam grafik di bawah ini:

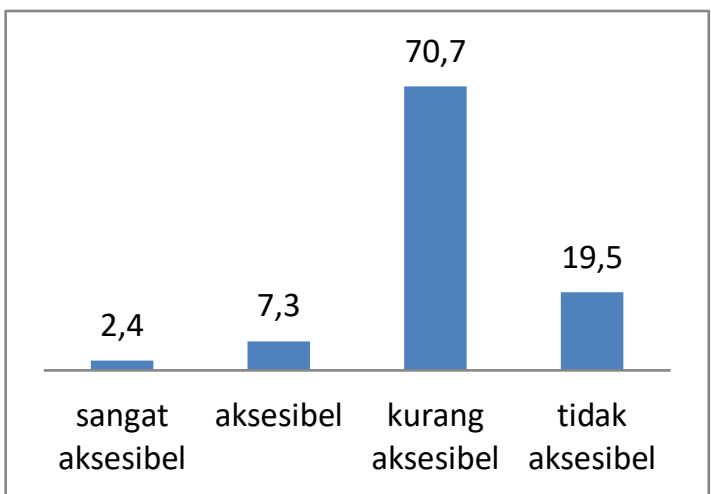

Figure 1. Aksesibilitas Tempat Publik

Sedangkan untuk pertanyaan kedua, jawaban para kelompok difabel cukup beragam dengan persebaran cukup merata, dan untuk lebih jelasnya akan diperlihatkan pada Grafik 2 di bawah. 13 koresponden (31,7 persen) mengaku tau dan paham tentang aturan aksesibilitas tempat publik. 11 koresponden (26,8 persen) tidak pernah mendengar terkait peraturan tersebut, 10 koresponden $(24,4$ persen) tahu tapi tidak paham, dan sisanya adalah sekitar 7 orang $(17,1$ persen) mengakui pernah mendengar regulasi tersebut tapi tidak tahu.

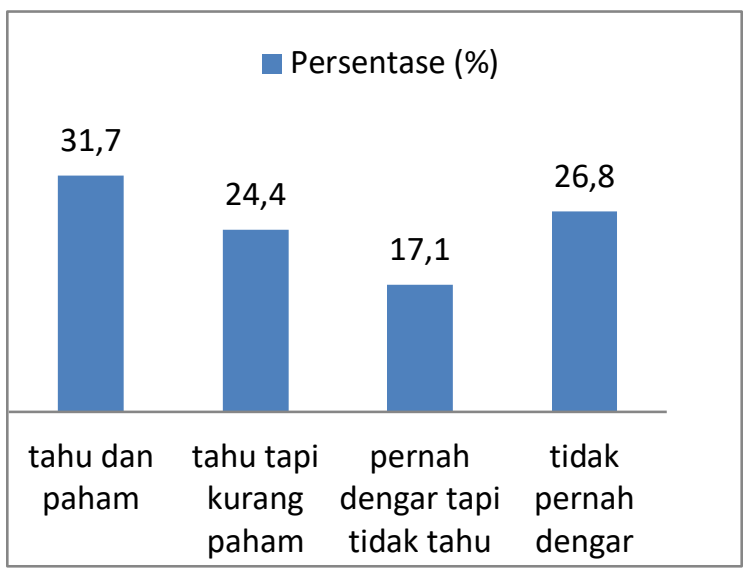

Figure 2. Pengetabuan Tentang Aturan Tempat Publik Harus Aksesibel

\section{- Aksesibilitas Sarana Transportasi}

Untuk mengetahui pemahaman kelompok difabel terkait aksesibilitas transportasi, digunakan empat pertanyaan yang diajukan. Pertanyaan diawali dengan menanyakan kelompok difabel "apakah sarana transportasi (seperti kereta api, angkot, bis, dan lainlain) dianggap sudah mengutamakan mereka sebagai kelompok difabel?" Jawabannya seperti yang terlihat dalam Grafik 3 di bawah ini:

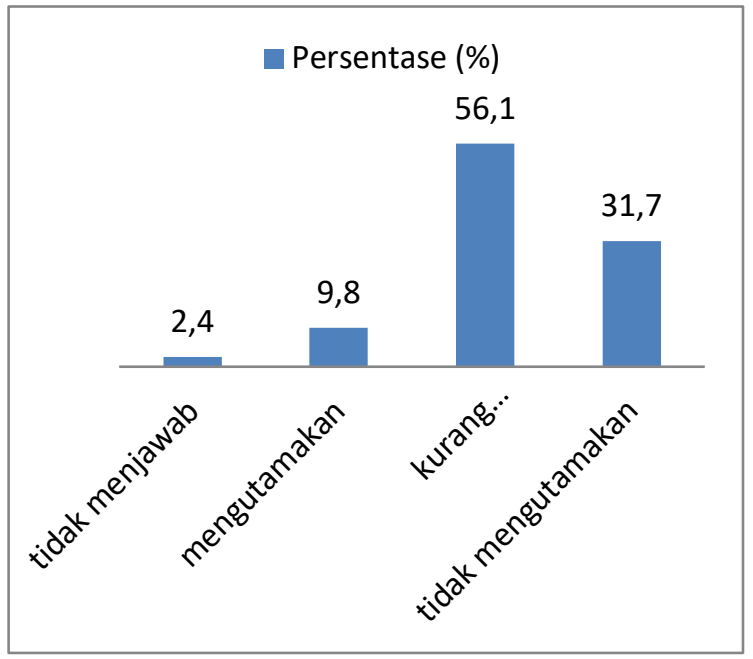

Figure 3. Pendapat Tentang Sarana Transportasi

Grafik di atas memperlihatkan bahwa sebagian besar kelompok difabel masih menganggap sarana transportasi belum memberikan pelayanan khusus terhadap kelompok difabel dengan persentase mencapai angka 56,1 persen. Bahkan 31,7 persen kelompok difabel menganggap saraa transportasi selama ini tidak mengutamakan kelompok disablitas. Sedangkan untuk koresponden yang menjawab mengutamakan hanya sekitar 9,8 persen dan sisanya menjawab tidak mengetahui.

Jawaban di atas akan bertolak belakang dengan regulasi yang telah diterapkan oleh pemerintah dalam bentuk UU, PP, Perda, maupun di dalam CRPD. Seperti pada UU No. 22 Tahun 2009 tentang Lalu Lintas dan Angkutan Jalan pasal 242 ayat 1 dan 2, di mana dengan tegas menyatakan pemerintah daerah dan perusahaan angkutan umum wajib memberikan perlakuan khusus bagi 
para difabel. Selanjutnya UU No. 43 Tahun 1998 tentang tentang Upaya Peningkatan Kesejahteraan Sosial Penyandang Cacat pasal 11 ayat 1 dan pasal 15 yang mengharuskan setiap penyelenggara angkutan memberikan fasilitas istimewa pada angkutan umum seperti tangga naik atau turun, tempat duduk, dan tanda-tanda pembantu. Peraturan tersebut juga diperkuat dengan munculnya Keputusan Menteri Perhubungan No. KM 71 Tahun 1999 terutama pada pasal Pasal 2 ayat 1 yang menyatakan bahwa "penyelenggara angkutan wajib melaksanakan pengangkutan penyandang cacat dan orang sakit dengan aman, selamat, cepat, lancar, tertib, teratur, dan nyaman".

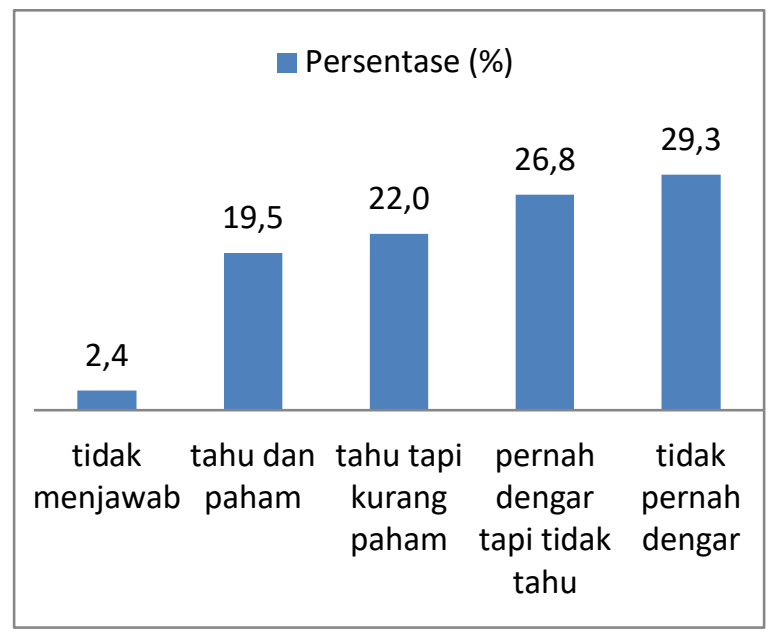

Figure 5. Pengetabuan Tentang Aturan Transportasi Harus Aksesibel

Namun ketika koresponden ditanyakan seputar regulasi tentang hak difabel dalam transportasi, jawaban koresponden cukup beragam, dimana sebagian besar koresponden menjawab tidak mengetahui keberadaan peraturan tersebut (lihat Grafik 4).

Berdasarkan data di atas maka dapat dipahami bahwa sebagian besar kelompok difabel tidak pernah mendengar peraturan atas aksesibilitas transportasi publik (29,3 persen). Adapun 26,8 persen kelompok difabel pernah mendengar tapi tidak mengetahui, 22 persen tahu tapi tidak paham. Sedangkan untuk yang telah tahu dan memahami hanya sekitar 19,5 persen. Rendahnya pemahaman ini juga berkorelasi dengan pemahaman lain kelompok difabel tentang transportasi, seperti misalnya aturan terkait dengan diskon yang diberikan oleh penyedia angkutan terhadap kelompok difabel yang menggunakan sarana angkutan umum.

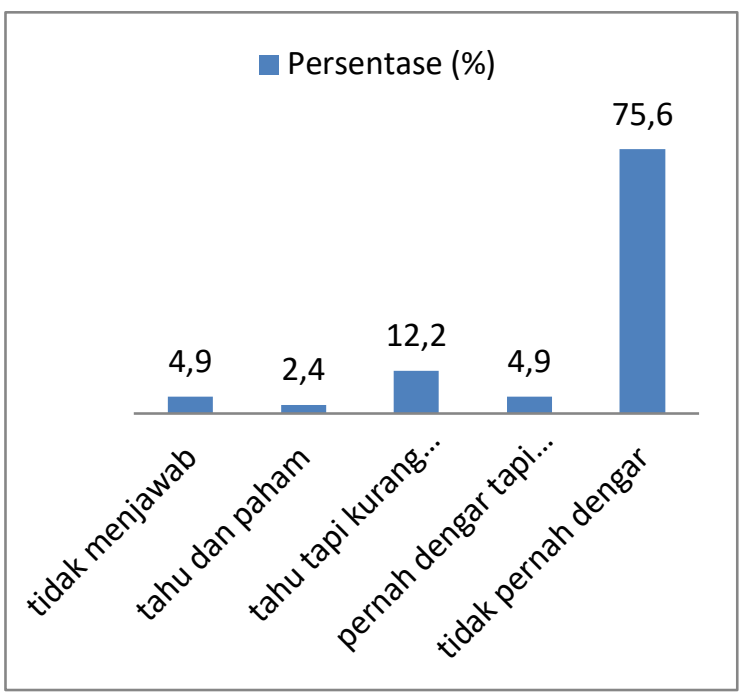

Figure 4. Pengetabuan Terkait Diskon Transportasi Bagi Kelompok Difabel

Berikut adalah temuannya:

Rendahnya pemahaman ini juga menjadi alasan mengapa kelompok difabel tidak pernah menuntut lebih terhadap pemerintah maupun penyedia sarana transportasi untuk memberikan pelayanan khusus serta lebih baik bagi mereka. Seperti ketika koresponden diajukan pertanyaan "apakah mereka pernah menuntut ke pemerintah agar perusahaan transportasi memberikan pelayanan khusus kepada mereka?" (untuk lebih jelasnya dapat dilihat dalam Grafik 6 di bawah). Jawabannya sudah dapat diprediksi, yakni 58,5 persen kelompok difabel tidak pernah menuntut hal tersebut. Sedangkan hanya 4,9 persen yang sering menuntut, 19,5 persen yang pernah menuntut, dan 12,2 persen yang 
jarang menuntut. Kondisi ini tentunya cukup memprihatinkan, di mana ketika kelompok difabel sendiri-pun tidak pernah menuntut hak dasar yang harusnya diberikan. Meskipun secara jelas berbagai regulasi telah mewajibkan hal tersebut.

\section{- Aksesibilitas Layanan Kesehatan}

Kesehatan merupakan kebutuhan pokok yang dibutuhkan oleh para kelompok difabel mengingat sebagian besar kelompok difabel bermasalah dengan kesehatan. Dalam sistem jaminan kesehatan terbaru posisi kelompok diabel juga belum jelas. Terutama ketika kebutuhan jaminan kesehatan kelompok difabel masih belum terakomodasi secara baik seperti dalam draft Perpres Jaminan Kesehatan (KPMAK UGM Online, 2017). Keadaan tersebut juga diperparah dengan belum adanya regulasi jelas terkait pemberian jaminan pelayanan kesehatan khusus bagi kelompok difabel.

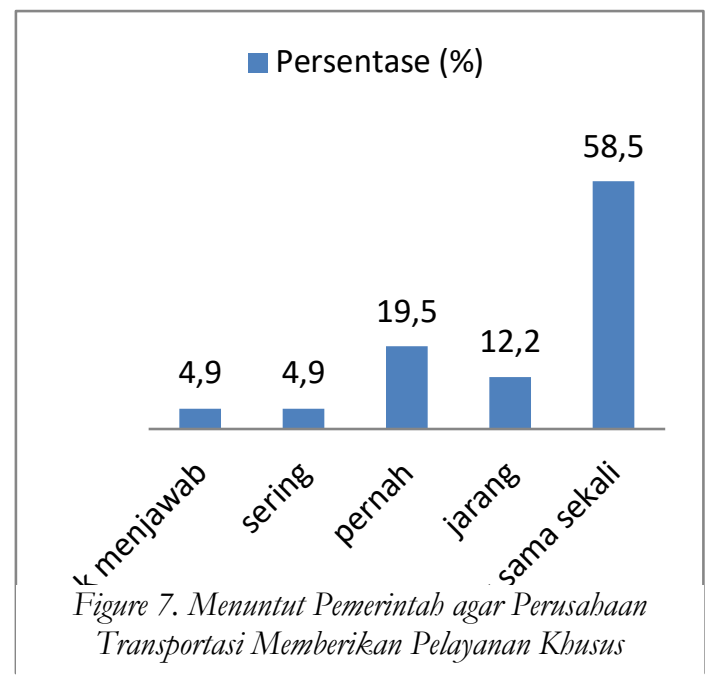

Untuk konteks Jawa Timur sendiri, kesulitan kelompok difabel dalam mengakses layanan kesehatan sedikit teratasi dengan dikeluarkannya Perda No. 3 Tahun 2013 tentang Perlindungan dan Pelayanan Bagi Penyandang Disabilitas. Secara khusus untuk konteks pelayanan kesehatan diakomodasi pada pasal 35 ayat 1,2 , dan 3 , yang berbunyi:
(1) Penyandang disabilitas dapat disetarakan dengan individu yang sehat jasmani dan rohani.

(2) Setiap penyandang disabilitas berbak mendapatkan layanan kesehatan yang bermutu sesuai dengan kondisi dan kebutuhan individu penyandang disabilitas.

(3) Setiap pemberi layanan kesehatan dilarang menolak pasien penyandang disabilitas yang membutubkan layanan kesehatan.

Namun apakah kelompok difabel mengetahui keberadaan peraturan ini, untuk membuktikannya pertanyaan pertama yang diajukan adalah dengan menanyakan hal sederhana seperti "sudahkan Anda diutamakan dalam antrean di tempat pelayanan kesehatan seperti puskesmas dan rumah sakit?" Jawaban para kelompok difabel tersebut kemudian terekam dalam Grafik 7 di bawah. Pada Grafik tersebut terlihat bahwa sekitar 48,8 persen kelompok difabel kurang diutamakan dalam hal antrean. Sekitar 29,3 persen menjawab tidak diutamakan, 19,5 persen sudah diutamakan, dan hanya 2,4 persen yang menjawab sangat diutamakan.

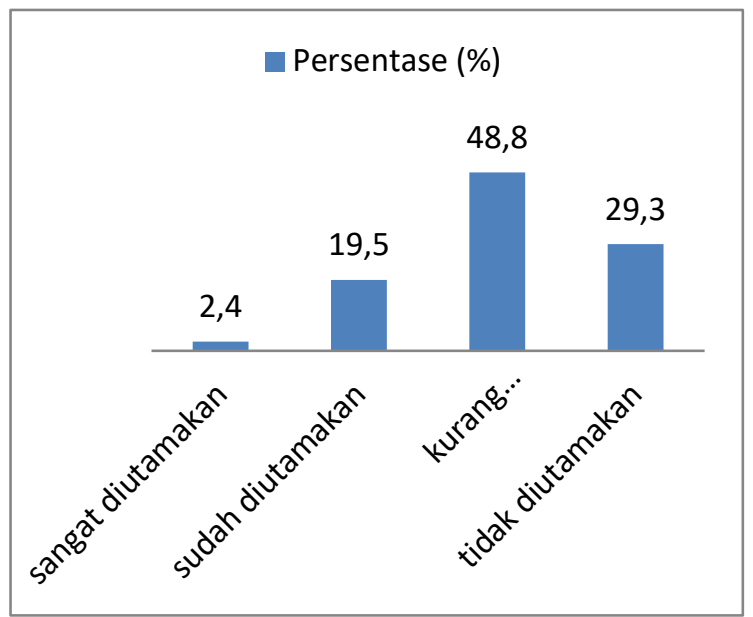

Figure 6. Pengutamaan Difabel dalam Antrian Layanan Kesehatan 
Bagaimana kemudian ketika kita membandingkan dengan pengetahuan difabel terkait larangan instansi kesehatan seperti puskesmas dan rumah sakit menolak pasien difabel. Hasilnya adalah sebagian besar koresponden kelompok difabel tidak mengetahui keberadaan regulasi tersebut. Meskipun seperti yang diungkan dalam Perda No. 3 Tahun 2013 terutama pasal 3 yang dengan tegas melarang pemberi layanan kesehatan menolak pasien difabel yang membutuhkan layanan kesehatan.

Dengan berbagai diskriminasi dan kurangnya pengetahuan yang dimiliki kelompok difabel berdampak pada upaya mereka untuk mendapatkan aksesibilitas. Hal ini terlihat dari minimnya upaya tuntutan yang dilakukan kelompok difabel. Untuk lebih jelasnya dapat dilihat dalam Grafik 8 di bawah ini:

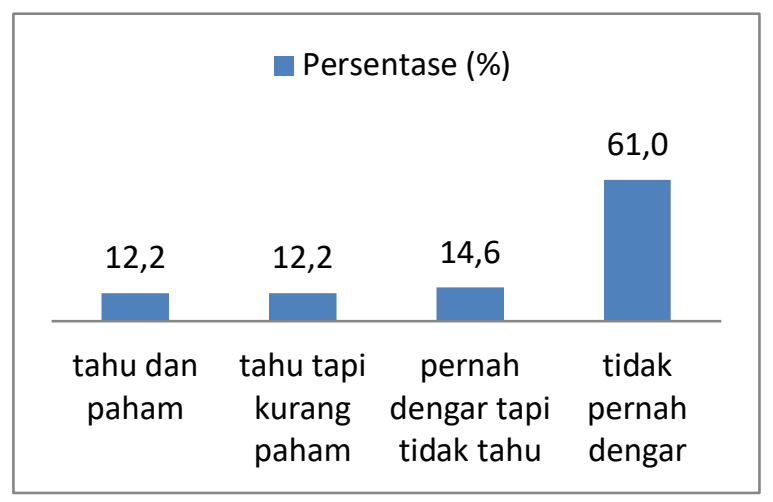

Figure 9. Pengetabuan Pelarangan Menolak Pasien Difabel

Data di bawah memperlihatkan bahwa hanya sekitar 4,9 persen kelompok difabel yang sering menyuarakan dan menuntut pemerintah memberikan pelayanan khusus. Hal kontras akan terlihat ketika dibandingkan dengan kelompok difabel yang tidak pernah menuntut pemerintah untuk memberikan pelayanan kesehatan khusus dengan jumlah mencapai 75,6 persen. Sedangkan hanya 14,6 persen masyarakat yang pernah berupaya menuntut pemerintah untuk memberikan pelayanan khusus dan
4,9 persen yang jarang melakukan hal tersebut.

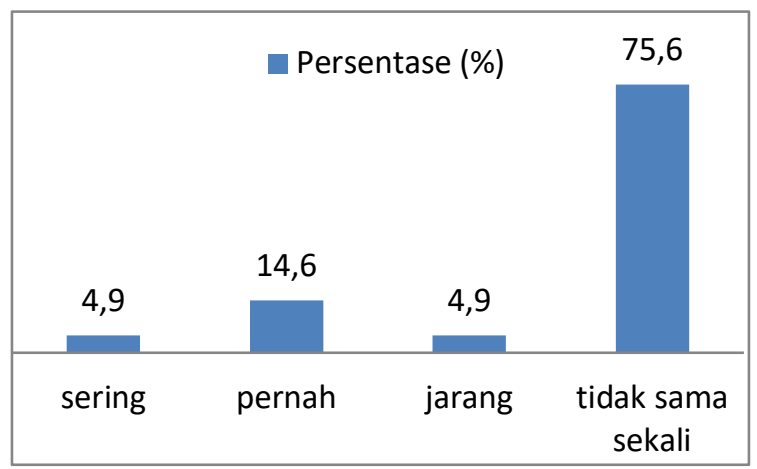

Figure 8. Menuntut Pemerintah Untuk Memberikan Pelayanan Khusus

\section{- Indikator Pendidikan Kelompok Difabel}

Indikator kedua yang digunakan untuk melihat pemahaman hak yang dimiliki berdasarkan Conventions on The Rights of Persons with Disabilities (CRPD) adalah indikator pendidikan. Diskriminasi bagi para kelompok difabel dalam pendidikan bukanlah suatu hal yang baru. Diskriminasi terjadi mulai dari tingkat pendidikan dasar hingga tingkat perguruan tinggi. Dalam beberapa kasus misalnya terlihat bahwa perguruan tinggi masih enggan menerima mahasiswa difabel karena diangap tidak cukup mampu bersaing dengan para mahasiswa normal. Salah satunya adalah syarat harus sehat jasmani dan rohani bagi masyarakat yang hendak mendaftar SBMPTN, hal itu bisa menimbulkan persepsi bahwa penyandang disabilitas tidak boleh ikut seleksi (Tirto Online, 2018). Di samping itu, beberapa kampus atau program studi juga masih enggan menerima mahasiswa difabel karena berbagai alasan. Dalam hal ini, Mohammad Bisri selaku rektor UB pada tahun 2017 pernah berbicara soal diperlukannya pedoman ilmiah dan relijius (fikih) untuk mendorong pengelola kebijakan lembaga pendidikan melakukan pelayanna terhadap penyandang disabilitas (Koran Republika Online, 2017). 
Hal tersebut juga dirasakan oleh para koresponden yang sebagian besar menjawab kurang diutamakan ketika mendapat pertanyaan "apakah pemerintah telah mengutamakan pendidikan bagi penyandang disabilitas?' Seperti terlihat pada data hasil Grafik 10 di bawah ini. Data di tersebut memperlihatkan bahwa sebagian besar kelompok difabel atau sekitar 68,3 persen merasakan bahwa pendidikan bagi mereka kurang diutamakan oleh pemerintah. Mereka merasakan bahwa pemerintah memposisikan mereka sebagai negara kelas dua dan berbeda dengan masyarakat normal pada umumnya. Sedangkan bagi 12,2 persen koresponden lainnya menganggap pemerintah tidak mengutamakan pendidikan kelompok difabel. Hanya sekitar 14,6 persen difabel merasa sudah mendapatkan keutamaan pendidikan dari pemerintah dan 2,4 persen merasa dirinya sangat diutamakan pemerintah dalam hal pendidikan.

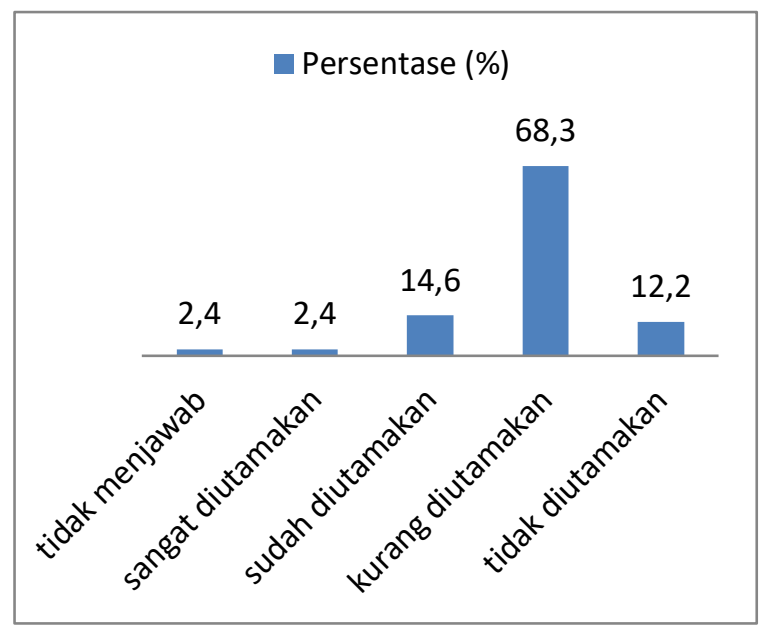

Figure 10. Pendidikan Bagi Kelompok Difabel

Data di atas merupakan bentuk negasi atas berbagai peraturan yang dikeluarkan pemerintah utamanya terkait perlakuan khusus yang seharusnya diberikan oleh lembaga pendidikan. UU No. 4 Tahun 1997 tentang Penyandang
Cacat pasal 12 dan Peraturan Menteri Pendidikan Nasional No. 70 Tahun 2009 tentang Pendidikan Inklusif bagi Peserta Didik yang Meliliki Kelainan dan Memiliki Potensi Kecerdasan dan atau Bakat Istimewa pasal 3 ayat 1 Peraturan Menteri Pendidikan Nasional No. 70 Tahun 2009 dengan tegas menyatakan bahwa kelompok difabel berhak mendapatkan pendidikan yang layak. Untuk mengakomodasi hal tersebut pemerintah maupun pemerintah daerah harus memberikan pendidikan inklusif bagi para difabel seperti yang tertuang dalam pasal 3 ayat 1 "setiap peserta didik yang memiliki kelainan fisik, emosional, mental, dan sosial atau memiliki potensi kecerdasan dan/atau bakat istimewa berhak mengikuti pendidikan secara inklusif pada satuan pendidikan tertentu sesuai dengan kebutuhan dan kemampuannya.

Selain itu pemerintah daerah daerah diwajibkan untuk mendirikan Sekolah Luar Biasa atau SLB dengan persentase minimal 1 SLB dalam setiap kecamatan seperti yang tertuang dalam pasal 4 ayat 1 Peraturan Menteri Pendidikan Nasional No. 70 Tahun 2009 yang menyatakan "bahwa Pemerintah kabupaten/kota menunjuk paling sedikit 1 (satu) sekolah dasar, dan 1 (satu) sekolah menengah pertama pada setiap kecamatan dan 1 (satu) satuan pendidikan menengah untuk menyelenggarakan pendidikan inklusif yang wajib menerima peserta didik sebagaimana dimaksud dalam Pasal 3 ayat (1)". Peraturan tersebut kemudian diperkuat dalam pasal 10 hingga 14 Perda No. 3 Tahun 2013 tentang Perlindungan dan Pelayanan Bagi Penyandang Disabilitas. Terutama untuk pasal 13 ayat (1) dan (2) pemerintah provinsi wajib menyediakan SLB bagi penyandang disabilitas karena derajat disabilitasnya tidak mampu mengikuti kelas terpadu atau inklusi. 
Meski demikian peraturan tersebut jauh dari ideal jika dikomparasikan dengan keadaan di lapangan karena masih banyak poin-poin yang diamanatkan peraturan di atas yang tidak dapat dipenuhi. Di samping itu, kelompok difabel juga kurang memahami keberadaan peraturan-peraturan tersebut. Hasil survey memperlihatkan bahwa koresponden sudah cukup memiliki pengetahuan terkait keberadaan SLB. Grafik di bawah ini memberikan gambaran tentang pemahaman difabel akan peraturan-peraturan tersebut.

Namun ketika dibandingkan dengan pertanyaan apakah para difabel mengetahui regulasi keharusan SLB harus terdapat setidaknya pada setiap kecamatan, jawaban akan sedikit berbeda.

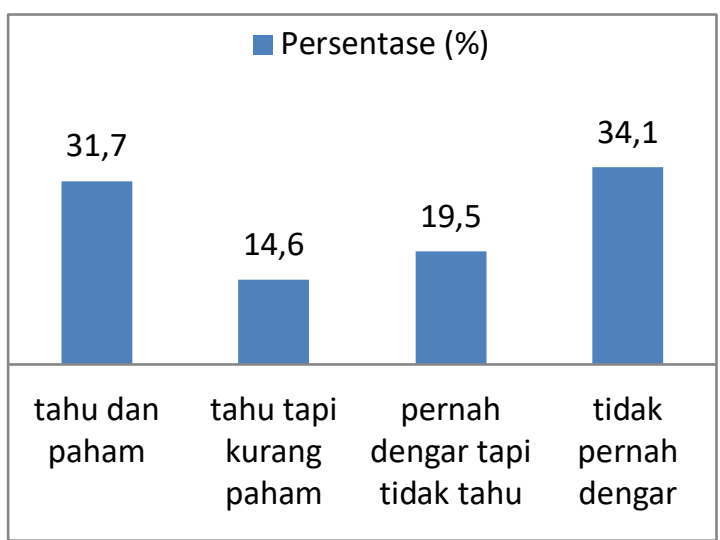

Figure 13. Pemahaman Difabel akan Peraturan tentang $S L B$

Sebagian besar atau 61 persen korenponden menjawab tidak mengetahui terkait peraturan keberadaan SLB, 17,1 persen pernah dengar tapi tidak tahu, 12,2 persen yang tahu dan paham, dan hanya 9,8 yang mengetahui regulasi tersebut meskipun kurang paham.

Hal serupa juga ditemukan terkait dengan hasil survey penggunaan status bahasa isyarat yang harus diakui dan disamakan dengan bahasa daerah lain. Seperti yang tergambarkan dalam sebaran data di bawah ini:

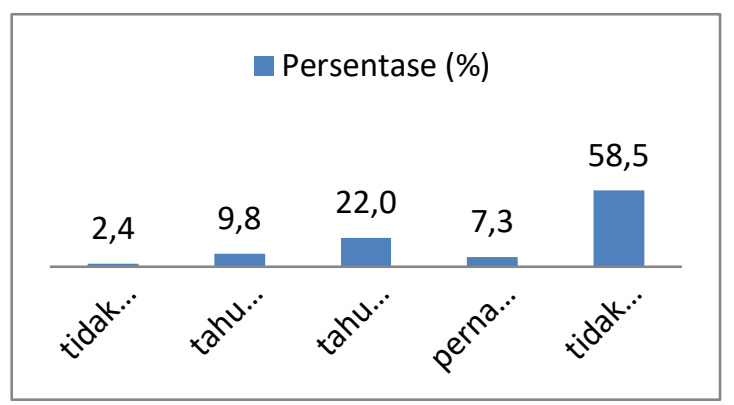

Figure 11. Pengetahuan Difabel akan Kewajiban SLB di Setiap Kecamatan

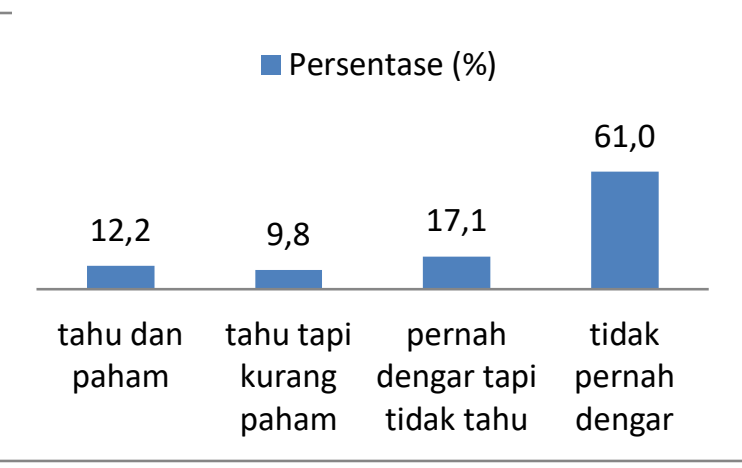

Figure 12. Penggunaan Status Bahasa Isyarat

Data di atas memperlihatkan bahwa 58,5 persen koresponden tidak pernah mendengar terkait regulasi tersebut sedangkan 22 persen mengetahui hal tersebut tetapi tidak terlalu paham konteks regulasi tersebut. Sedangkan 9,8 persen koresponden mengetahui serta paham keberadaan regulasi tersebut dan 7,3 persen koresponden mengaku pernah mendengar tetapi tidak tahu terkait hal tersebut.

\section{- Indikator Ekonomi Kelompok Difabel}

Keterpurukan kelompok difabel dalam konteks ekonomi didasarkan pada dua gagasan utama, pertama adalah sulitnya para kelompok difabel dalam mengakses jasa keuangan. Dengan banyaknya lembaga keuangan seperti bank atau koperasi bukanlah jaminan bahwa kelompok difabel dengan mudah mendapat pinjaman khususnya untuk modal usaha. Kelompok difabel juga semakin terpuruk dengan rendahnya 
kesadaran mereka terkait dengan keuangan (financial litirate) (Thohari, dkk, 2013). Argumen ini akan bertolak belakang dengan Perda No. 3 Tahun 2013 tentang Perlindungan dan Pelayanan Bagi Penyandang Disabilitas. Pada pasal 23, di mana secara garis besar menjabarkan kewajiban pemerintah provinsi untuk mempermudah akses pinjaman modal ke lembaga keuangan seperti bank atau dalam bentuk hibah. Tidak berhenti sampai di situ, selanjutnya pada pasal 29 pemerintah provinsi juga wajib memberikan keringanan bunga dibandingkan masyarakat pada umunya.

Pertanyaannya kemudian adalah keistimewaan kelompok difabel yang diatur dalam regulasi ini apakah sudah dirasakan? Berdasarkan survey yang dilakukan jangankan mendapatkan kemudahan akses pinjaman dan keringanan bunga, kelompok difabel saja belum mengetahui bahwa terdapat regulasi tersebut. Seperti yang terlihat pada sebaran data survey di bawah ini:

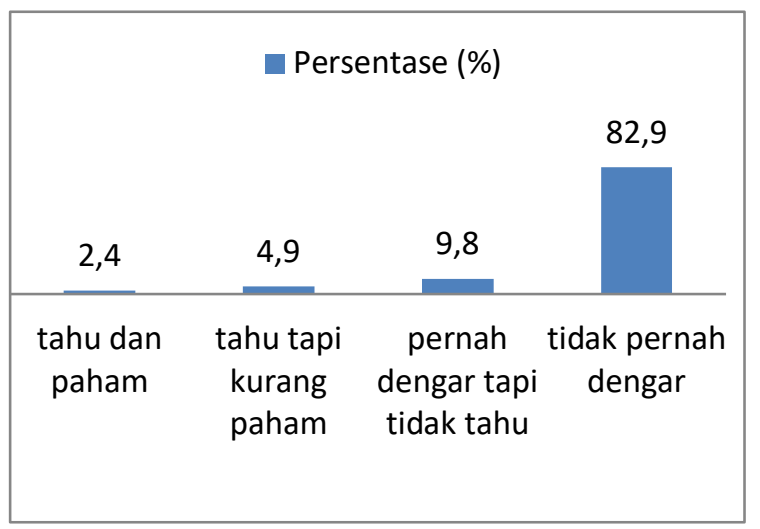

Figure 14. Pengetahuan tentang Bantuan Pemerintah untuk Kredit Bagi Difabel

Data di atas memperlihatkan bahwa 82,9 persen koresponden kelompok difabel tidak mengetahui keberadaan regulasi ini. Angka tersebut sangat kontras jika dibandingkan dengan jumlah koresponden yang tahu dan paham yang hanya 2,4 persen, tahu tetapi tidak paham 4,9 persen, dan pernah dengar tetapi tidak mengetahui secara spesifik sebesar 9,8 persen.

Argumen kedua terkait keterpurukan ekonomi kelompok difabel datang dari sikap diskriminasi dunia kerja karena menganggap difabel merupakan batasan dalam melakukan pekerjaan. Selama ini dunia kerja merupakan dunia yang tidak bersahabat dengan kelompok difabel terutama pada-sektor formal seperti perusahaan. Hanya sedikit perusahaan memiliki keinginan untuk merekrut kelompok difabel. Kelompok difabel seperti terisolasi dan tidak memiliki pilihan lain selain membuka lapangan pekerjaan sendiri pada sektorsektor informal. Paradigma ini seperti mengakar cukup kuat bagi perusahaanperusahaan sehingga enggan menerima pekerja dari kelompok difabel. Meskipun misalnya difabel tersebut memiliki kualifikasi setara bahkan lebih dengan pekerja normal.

Diskriminasi ini kemudian coba untuk dirubah, salah satunya adalah dengan mengeluarkan beberapa peraturan terkait kesemaan hak di bidang pekerjaan. Kesamaan kesempatan mendapatkan pekerjaan bagi kelompok difabel terdapat pada UU No. 4 Tahun 1997 tentang Penyandang Cacat pasal 13 dan pasal 14. Para difabel mendapatkan hak dan kesempatan yang sama untuk mendapatkan pekerjaan, baik dari perusahaan milik negara maupun perusahaan swasta. Jumlah pegawai difabel dalam satu perusahaan juga tidak luput dari perhatian, berdasarkan PP No. 42 Tahun 1998 tentang Upaya Peningkatan Kesejahteraan Sosial Penyandang Cacat pasal 28, dinyatakan bahwa setidaknya harus terdapat 1 orang difabel yang memenuhi kualifikasi dari 100 orang pekerja. Hal tersebut kemudian diperkuat dalam Perda No. 3 Tahun 2013 tentang Perlindungan dan 
Pelayanan Bagi Penyandang Disabilitas pasal 16 ayat 3 .

Berdasarkan pertanyaan survey yang diberikan terkait dengan jumlah tenaga kerja difabel dalam 100 orang tenaga kerja normal, sebagian koresponden mengetahui hal tersebut namun tidak memeahami secara spesifik, seperti terlihat dalam grafik di bawah ini. Selanjutnya grafik tersebut memperlihatkan bahwa kelompok difabel mengetahui regulasi tersebut namun tidak paham maksudnya. Sedangkan hanya sekitar 19,5 persen korenponden yang tidak mengetahui hal tersebut, 12,2 persen yang pernah dengar tetapi tidak memehami secara spesifik.

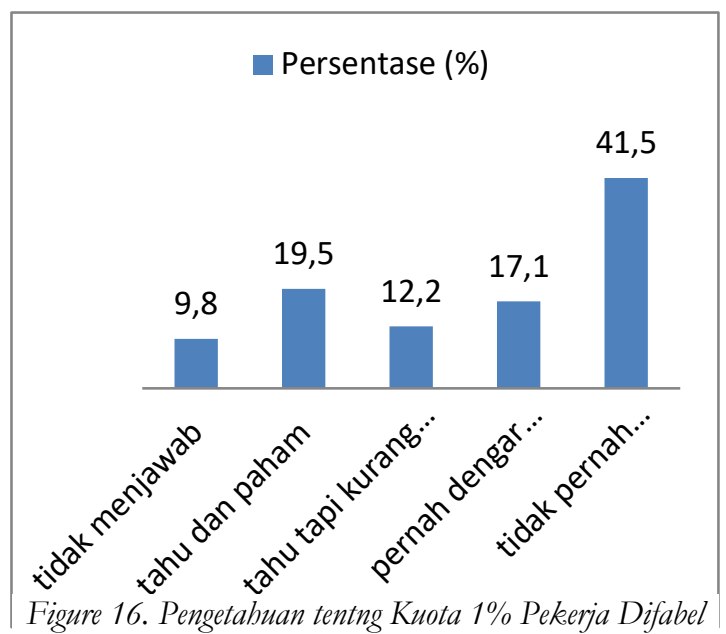

Pada bagian lain juga ditanyakan apakah kelompok difabel mengetahui adanya peraturan yang mengatur tentang kesamaan gaji pekerja penyandang disabilitas dan pekerja lain. Hal tersebut sesuai dengan PP No. 42 Tahun 1998 tentang Upaya Peningkatan Kesejahteraan Sosial Penyandang Cacat terutama pasal 26, 27, dan 31. Maupun juga berdasarkan Perda No. 3 Tahun 2013 tentang Perlindungan dan Pelayanan Bagi Penyandang Disabilitas pasal 17 ayat (1) dan (2), di mana masingmasing menegaskan kesamaan derajat maupun hak antara pekerja difabel dan pekerja normal. Hasilnya adalah seperti dalam grafik di bawah ini:

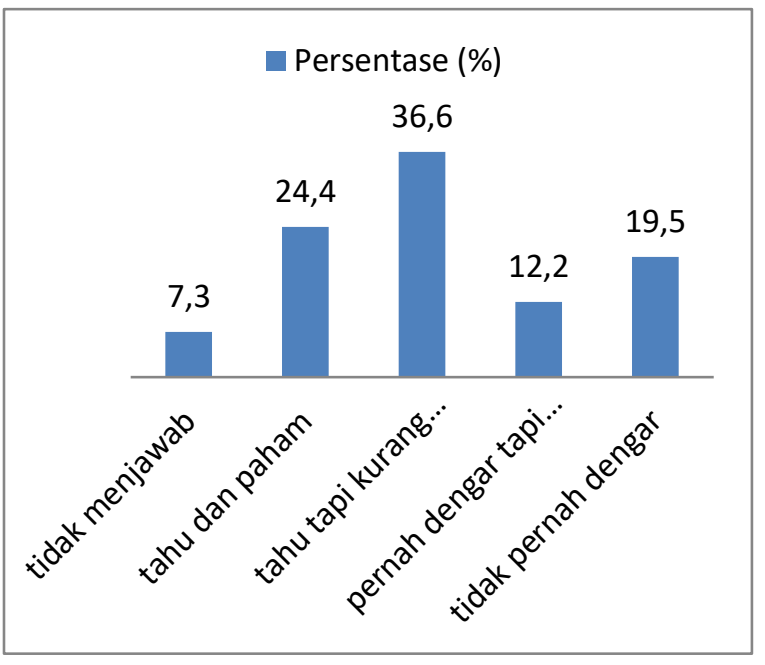

Figure 15. Pengetabuan Kesamaan Hak antara Pekerja Difabel dan Normal

Sebaran data survey grafik di atas terlihat begitu sangat kontras, di mana sekitar 41,5 persen atau hampir setengah koresponden mengaku tidak pernah mendengar regulasi tersebut. $\mathrm{Hal}$ tersebut memang tidak begitu mengagetkan, karena dalam undangundang-pun hanya dikatakan kesamaan derajat dan hak, namun tidak dinyatakan melalui redaksional persamaan gaji.

Selain kemudahan pinjaman dan kesamaan derajat/ hak dalam persusahaan. Pemerintah juga mengupayakan pelatihan kerja bagi para difabel baik untuk mempersiapkan kerja untuk sektor formal maupun informal. Peraturan tersebut mengharuskan kelompok difabel mendapatkan pelatihan kerja baik dari pemerintah melalui Badan Latihan Kerja (BLK) yang terdapat di daerah-daerah , swasta, maupun masyarakat sesuai dengan bunyi pasal 18 ayat (1) dan (2). Untuk hal ini jawaban koresponden relatif berimbang, di mana antara tahu dan paham dan tidak pernah dengar tidak jauh berbeda namun persentase tahu dan paham sedikit lebih besar yakni 36,6 persen dibandingkan dengan tidak pernah dengar sebesar 29,3 
persen. Pada tiga jawaban lainnya sebarannya juga cukup merata, di mana 14,6 persen menjawab tahu tapi kurang memahami secara spesifik, 12,2 persen pernah dengar tetapi tidak memahami secara spesifik, dan 7,3 persen memilih untuk tidak menjawab.

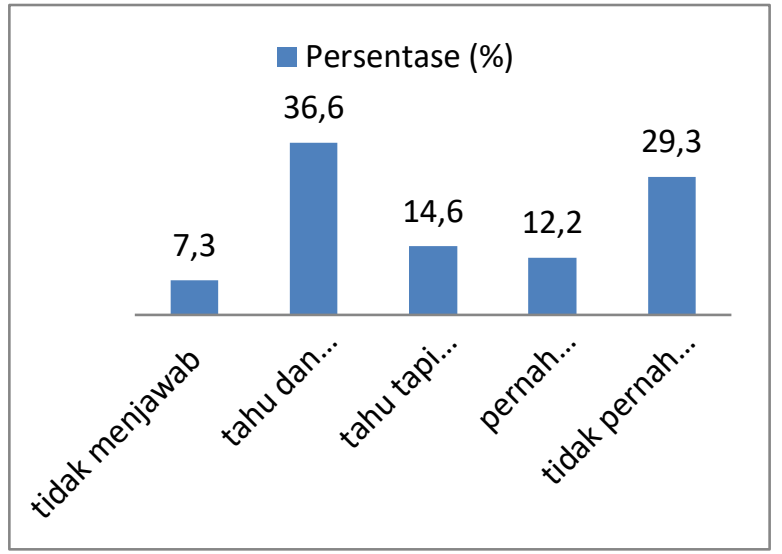

Figure 17. Pengetabuan Tentang Peraturan Pelatihan Kerja bagi Difabel

Adapun secara keseluruhan pandangan kelompok difabel terkait indikator ekonomi (pekerjaan) terangkum dari muatan pertanyaan terakhir. Pertanyaan ini menyatakan bahwa apakah dalam pekerjaan kelompok difabel masih menerima perlakuan diskriminatif baik instansi pemerintah maupun swasta. Hasilnya adalah sebagaian besar kelompok difabel menganggap sebagian besar lingkungan

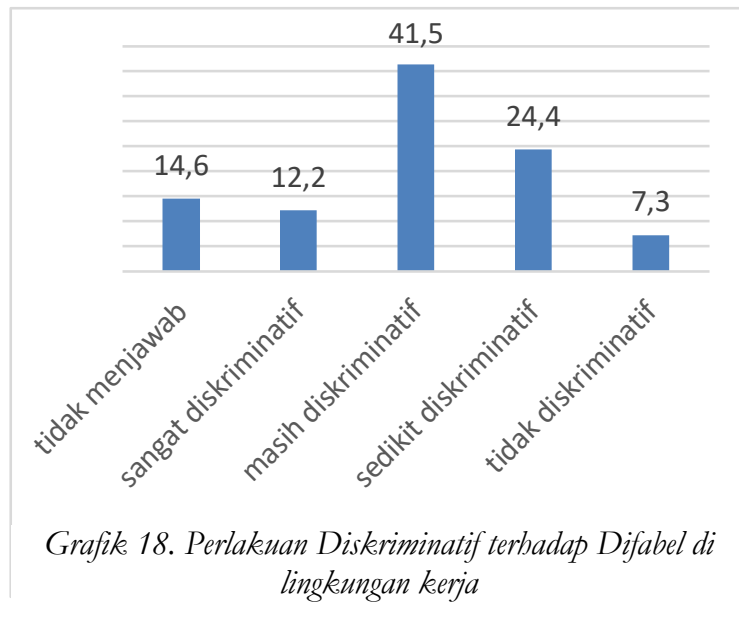

kerja masih menunjukkan prilaku diskriminatif atau sekitar 41,5 persen. Meskipun dengan berbagai kemudahan dan keistimewaan dari berbagai peraturan, tidak serta merta menghilangkan mindset masyarakat normal bahwa difabel itu berbeda dan merupakan sebuah kecacatan.

\section{- Indikator Persamaan Hukum Kelompok Difabel}

Bagi sebagaian kelompok difabel hukum merupakan ranah yang sudah pasti sangat tidak ramah dengan kamu difabel. Salah satu bentuk diskriminasi tersebut terlihat ketika kelompok difabel menjadi saksi dalam persidangan. Dalam Kitab Undang-Undang Hukum Pidana (KUHP), saksi difabel tidak termasuk sebagai saksi penuh, yang artinya tidak mampu melihat mendengar dan mengalami (Kompasiana.com, 2014). Kesaksian kelompok difabel masih dianggap terhambat oleh kemampuan mereka baik berupa mental dan fisik.

Lemahnya posisi kelompok difabel di mata hukum telah berusaha dirumuskan dalam Perda No. 3 Tahun 2013 tentang Perlindungan dan Pelayanan Bagi Penyandang Disabilitas terutama pasal 55 ayat (1) hingga (5). Dalam pasal tersebut kelompok difabel dijamin secara hukum, dengan jalan mendapatkan bantuan hukum. Bantuan hukum tersebut meliputi tiga hal, yakni pendampingan, pembelaan, dan tindakan hukum lainnya baik dari advokat maupun lembaga-lembaga hukum. Dalam memperoleh pembelaan hukum tersebut kelompok difabel tidak dipungut biaya. Meskipun demikian, masih banyak kelompok difabel menganggap kurangnya bantuan hukum terhadap mereka terutama yang datang dari pemerintah.

Data di atas dapat dipahami mengingat lemahnya pengetahuan 
masyarakat terhadap perlindungan hukum yang seharusnya diberikan oleh pemerintah seperti yang telah dijelasakan Perda Provinsi Jawa Timur di atas.

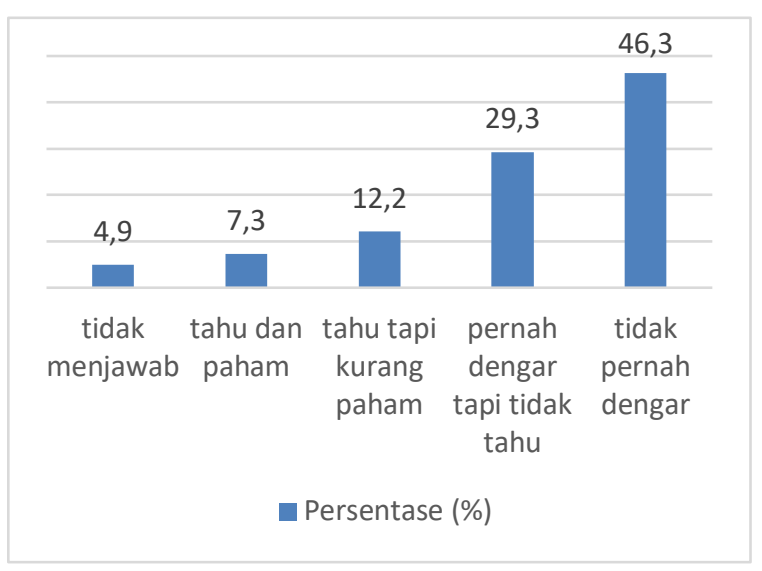

Figure 20. Bantuan dalam Proses Hukum

Lemahnya pengetahuan tersebut dapat dibaca dari survey yang dilakukan dengan pertanyaan "apakah anda pernah mendengar bahwa penyandang disabilitas berhak mendapatkan perlindungan hukum dari pemerintah?" Sebagian besar responden mengaku bahwa tidak pernah mendengar adanya regulasi terakait dengan bantuan hukum yang diberikan oleh pemerintah seperti yang akan dijelaskan grafik 20 di bawah ini. Besaranya angka ketidaktauan kelompok difabel tersebut mencapai 46,3 persen, jauh di bawah koresponden yang mengaku pernah mendengar tetapi tidak mengetahui secara spesifik terkait regulasi sebesar 29, 3 persen. Masyarakat yang tahu tapi tidak paham secara spesifik jumlahnya 12,2 persen dari total koresponden dan 7,3 persen meyatakan tahu dan paham.

\section{Dampak dari kurangnya} pengetahuan masyarakat difabel di bidang hukum pada akhirnya berimplikasi pada lembaga mana tempat kelompok difabel mengadukan kasus diskrimininasi yang dihadapi. Dengan mengajukan berbagai pilihan mulai dari polisi, pemerintah, hingga satuan terkecil

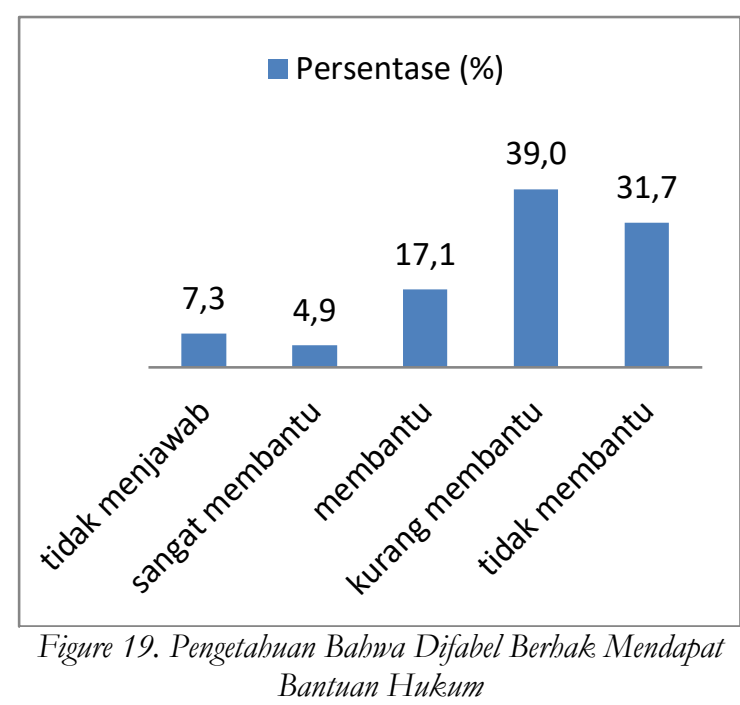

seperti RT, kelompok difabel masih tetap tidak mengetahuinya. Untuk pertanyaan ini jawaban terbesar koresponden yakni tidak tahu yang jumlahnya 41,5 persen. Sedangkan untuk pilihan lain kelompok difabel memilih Ombudsman sebagai lembaga yang dapat dijadikan sebagai tempat mengadukakan kasus diskriminasi dengan jumlah sebesar 14,6 persen. Selanjutnya berturut-turut legislatif sebesar 12,2 persen, pemerintah 9,8 persen, polisi 3 persen, RT 2 persen, serta lembaga-lembaga lain 2,4 persen. Hasil tersebut memperlihatkan bahwa kelompok difabel memilik persepsipersepsi berbeda terkait dengan lembaga mana yang paling tepat untuk melaporkan kasus diskriminasi yang dihadapi. Gambaran akan persebaran angka survey tersebut untuk lebih jelasnya dapat dilihat dalam grafik $21 \mathrm{di}$ bawah ini: 


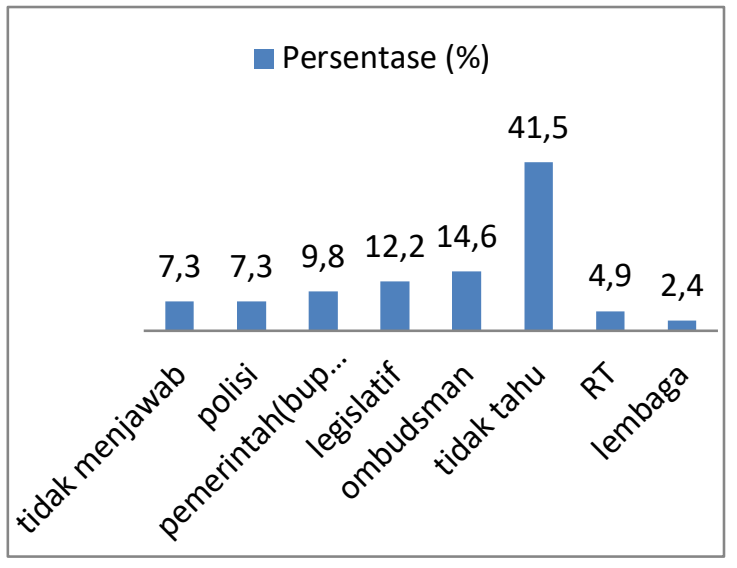

Figure 21. Pendapat Kemana Seharusnya Diskriminasi Dilaporkan

Pertanyaan terakhir yang diajukan kepada oresponden adalah terkait dengan Tim Koordinasi dan Pengendalian Peningkatan Kesejahteraan Sosial (TKP2KS) daerah. TKP2KS dibentuk mulai dari tingkat nasional yang diketuai oleh menteri sosial hingga ke tingkat daerah. Hasil survey tersebut tergambarkan dalam diagram di bawah ini:

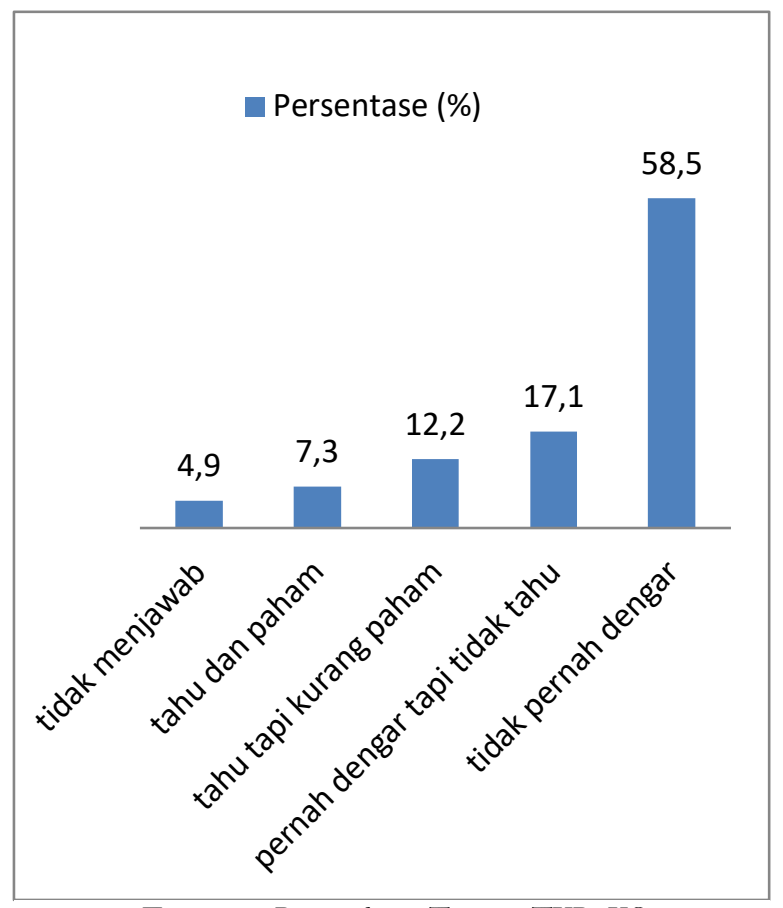

Figure 22. Pengetahuan Tentang TKP2KS

Diagram di atas memperlihatkan bahwa sebagian besar responden atau 58,5 persen tidak pernah mendengar tentang keberadaan TKP2KS. 17,1 responden mengaku bahwa pernah mendengar tapi tidak memahami tugas maupun fungsi lembaga tersebut. 12,2 persen koresponden mengetahui kereadaan lembaga tersebut, namun tidak paham secara spesifik, dan hanya 7,3 persen koresponden yang tahu dan paham keberadaan TKP2KS. Artinya bahwa dapat disimpulkan lembaga strukturan dengan fungsi cukup vital bagi kelompok difabel inipun tidak familiar di tengah kelompok difabel itu sendiri.

\section{Penutup}

Data hasil penelitian yang telah dipaparkan pada bab sebelumnya secara umum memberikan informasi penting bagi kita dan difabel untuk memahami bagaimana Convention on the Rights of Persons with Disabilities/CRPD (Konvensi Hak-hak Penyandang Disabilitas) yang kemudian diratifikasi oleh pemerintah Indonesia menjadi UU No. 19 Tahun 2011 tentang Pengesahan Convention On The Right of Persons With Disabilitie (Konvensi Mengenai Hak-Hak penyandang Disabilitas) diimplementasikan. Secara umum, dari empat indikator hak penyandang disabilitas yang ada dalam peraturan tersebut, yaitu aksesibilitas, hak pendidikan, hak ekonomi dan hak kesetaraan di depan hukum, hampir semuanya belum bisa dikatakan baik dan aksesibel bagi penyandang disabilitas.

Indikator aksesibilitas tempat publik dinilai kurang aksesibel. Sedangkan, sarana transportasi publik juga memperlihatkan akses yang tidak ramah bagi difabel $(56,1 \%$ menilai tidak mengutamakan difabel). Dalam bidang kesehatan, pelayanan kesehatan yang diterima oleh difabel juga tidak ramah, terbukti dengan pendapat yang mengatakan bahwa tidak ada pengutamaan bagi difabel dalam hal 
antrian sebesar 48,8\%. Hak pendidikan pun juga tidak jauh berbeda, sebagian besar responden $(68,3 \%)$ menilai tidak mendapatkan pelayanan pendidikan yang ramah difabel. Dalam hal hak ekonomi, perlakuan diskriminatif di tempat kerja masih sering dirasakan, 41,5\% responden merasakan hal itu. Di depan hukum, 39\% responden merasakan kurang mendapat bantuan saat di depan hukum dan 31,7\% merasa tidak terbantu sama sekali. Kondisi tersebut juga disertai dengan minimnya pengetahuan dan pemahaman difabel tentang hak-haknya yang ada di dalam regulasi. Penyandang disabilitas juga tidak menuntut hak mereka meskipun belum dipenuhi oleh pemerintah.

\section{References}

Pawestri, Aprilina. 2017, "Hak Penyandang Disabilitas dalam Perspektif $H A M$ International dan $H A M$ Nasional", Jurnal Era Hukum Vol. 2 No. 1, Juni 2017

Slamet Thohari, Dkk. (2013). Baseline dan Aksesibilitas bagi Penyandang Disabilitas di Kota Malang. Malang: PSLD. 2013. Hlm. 38.

Slamet Thohari, Rachmad Gustomy, dan Ulfa Fatmala R. (2013) Buku Panduan Financial Literacy: Bagi Penyandang Disabilitas. Malang: OJK dan PSLD. Hlm. 2.

Undang-Undang No 19 Tahun 2011 tentang Pengesahan Convention On The Rights of Persons With Disabilities

Undang-Undang No. 28 Tahun 2002 tentang Bangunan Gedung

Keputusan Menteri Perhubungan No. KM 71 Tahun 1999 Aksesibilitas Bagi Penyandang Cacat Dan
Orang Sakit Pada Sarana Dan Prasarana Perhubungan

Peraturan Menteri Pendidikan Nasional No. 70 Tahun 2009

Hospita, Maria Elisa. 2018. WHO: Jumlah Penyandang Disabilitas Meningkat Setiap Harinya.

https://www.aa.com.tr/id/d unia/who-jumlah-

penyandang-disabiltas-duniameningkat-setiapharinya/1328256\# diakses pada Senin, 31 Agustus 2020 pukul 7:55 WIB

International Labour Organization (ILO), tanpa tahun, Inklusi Penyandang Disabilitas di Indonesia, di akses pada Senin, 31 Agustus 2020 pukul 7:49 WIB

Kustiani, Rini. 2019. Berapa banyak Penyandang Disabilitas di Indonesia? Simak data ini. https://difabel.tempo.co/rea d/1266832/berapa-banyakpenyandang-disabilitas-diindonesia-simak-data-ini diakses pada Senin, 31 Agustus 2020 pukul 8:06 WIB

http://ppdi.co/kronologis-upayaratifikasi-the-cconventionon-the-rights-of-personswith-disabilities / diakses pada tanggal 23 April 2014

http://pusham.uii.ac.id/index.php?\&pa ge $=$ event\&id $=119$ berjudul "Pemenuhan Hak Atas Peradilan yang Fair bagi Penyandang Disabilitas". Pada hari Rabu 23 April 2016 pukul 23.40.

http://www.kpmak-ugm.org dengan artikel berjudul "Menjamin Difabel dalam BPJS 
Kesehatan" pada tanggal 14 Oktober pukul 22.13.

Primastika, Widia. 2018, Penyandang Disabilitas Masih Sulit Mengakses Perguruan Tinggi, https://tirto.id/penyandangdisabilitas-masih-sulitmengakses-perguruan-tinggic6am diakses pada 31 Agustus 2020 Pukul 8.34 WIB

Fizriyani, Wilda. 2017, Peyandang Disabilitas Masih Rentan ditolak di Kampus, https://www.republika.co.id /berita/pendidikan/duniakampus/18/01/04/p1d00w3 35-penyandang-disabilitasmasih-rentan-ditolak-dikampus diakses pada 31 Agustu 2020 Pukul 8:42 WIB 